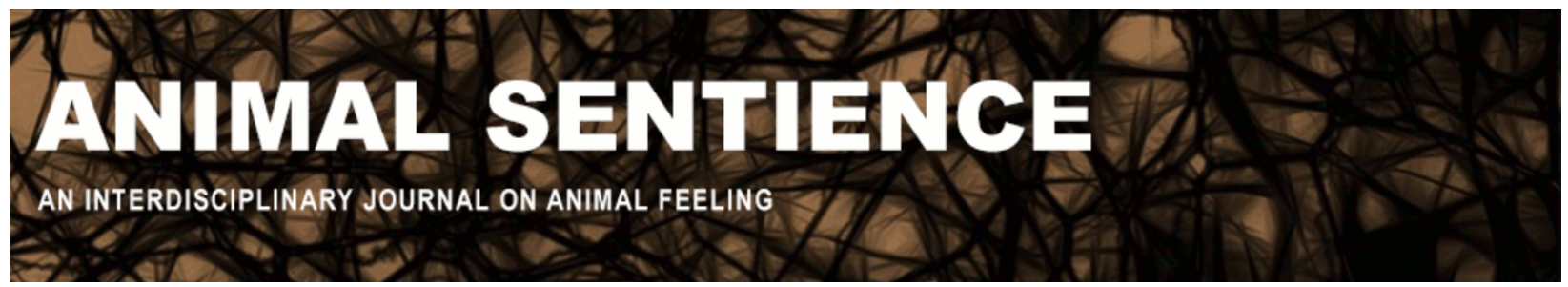

Baker, Liv and Winkler, Rebecca (2020) Asian elephant rescue, rehabilitation and rewilding. Animal Sentience 28(1)

DOI: 10.51291/2377-7478.1506

Date of submission: 2019-07-17

Date of acceptance: 2020-01-20

(c)

This article has appeared in the journal Animal

Sentience, a peer-reviewed journal on animal

cognition and feeling. It has been made open access,

free for all, by WellBeing International and deposited

in the WBI Studies Repository. For more information,

please contact

wbisr-info@wellbeingintl.org.

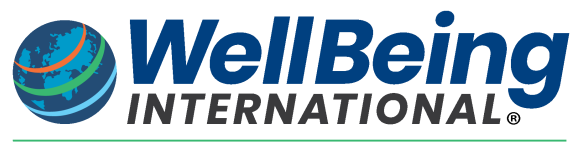

SOLUTIONS FOR PEOPLE, ANIMALS AND ENVIRONMENT 
Call for Commentary: Animal Sentience publishes Open Peer Commentary on all accepted target articles. Target articles are peer-reviewed. Commentaries are editorially reviewed. There are submitted commentaries as well as invited commentaries. Commentaries appear as soon as they have been reviewed, revised and accepted. Target article authors may respond to their commentaries individually or in a joint response to multiple commentaries.

INSTRUCTIONS FOR COMMENTATORS

\title{
Asian elephant rescue, rehabilitation and rewilding
}

\author{
Liv Baker \\ Animal Behavior and Conservation Program, Hunter College \\ Rebecca Winkler \\ Department of Anthropology, University of Pennsylvania
}

\begin{abstract}
Thailand has fewer than 10,000 elephants left. More of them are living in captivity to serve the tourist industry under grim conditions than are living free in what is left of their wild habitat. Conservation efforts need to be focused on all surviving members of the species, captive and free, but they need to take into account the inextricable entanglement of human and nonhuman animal lives in Thailand today. There is an opportunity for rescuing, rehabilitating and reintroducing captive elephants to the wild with the help of the traditional expertise of a mahout culture that has been elephant-keeping for centuries. We advocate a state of wildness that is meaningful to the elephants and can be attained in a way in which both elephant and human cultures are valued. This would be far better than the status quo for the elephants, restoring to them a life worth living.
\end{abstract}

Keywords: animal welfare, Anthropocene, captivity, compassionate conservation, elephants, ecotourism, rewilding, wildness
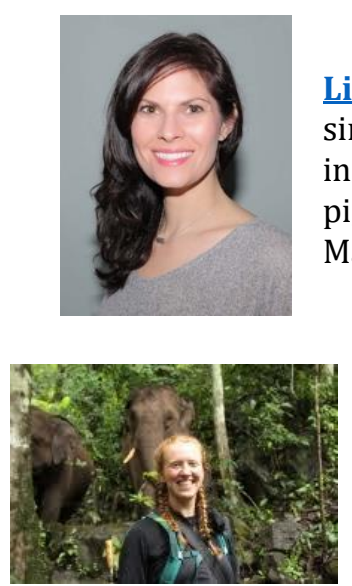

Liv Baker, conservation behaviorist and expert in wild animal welfare, explores similar patterns of wellbeing seen across the animal kingdom. Her work includes elephants, cetaceans, primates, arachnids, rodents, macropods, and pigs. Liv teaches at Hunter College, CUNY, and is the research director with Mahouts Elephant Foundation, UK. Website

Rebecca Winkler is a PhD student in the Department of Anthropology at the University of Pennsylvania with interest in animal studies and multidisciplinary environmental justice. Rebecca consults for Mahouts Elephant Foundation on their ongoing projects. Website 


\section{Introduction}

As wildlife populations dwindle, billions of wild animals are now living in various forms of captivity throughout the world (Mason, 2010). In many cases the demand for captive animals is driving free-living populations to the edge of existence. A case in point is the endangered Asian elephant (Maurer et al., 2017). In Asian elephant range countries, the wild population is estimated at 30-50,000 individuals (Sukumar, 2006; Choudhury et al., 2008), with another $10-15,000$ living in some form of captivity (Maurer et al., 2017). In the 21 $1^{\text {st }}$ century, when wildness is more aspirational than actual, the captive Asian elephant population presents an important conservation opportunity (Campos-Arceiz, 2016). The conservation and animal protection communities concerned about the lives of Asian elephants and the survival of their species must address the question of the near 15,000 Asian elephants held captive in range countries (Campos-Arceiz, 2016): These too are members of the endangered species, Elephas maximus, equally needful of the efforts and protections afforded all members of the species.

Thailand offers an instructive case study for the conservation and protection of animals within their rangeland. Among the confluence of pertinent factors is the situated knowledge of Karen hilltribe mahouts (traditional elephant-keepers) as well as the desire and political will (Young, 2004) of certain communities to preserve their cultural identities as elephant guardians and forest protectors (Anan, 2000; Walker, 2001). To avoid potential misconstrual of this target article's thesis as a cultural defense of exploitative practices, we wish to make it clear that we are in no way suggesting that practices that permit and perpetuate violence and exploitation of nonhuman and human individuals should be defended on the grounds of tradition. If we are to design future human-elephant relations that privilege compassion, we must work to understand the diversity of ways human communities relate to elephants. Those relations are manipulated by power structures that affect vulnerable populations of nonhumans and humans alike. As Gaard (1993) writes: "the ideology which authorizes oppressions such as those based on race, class, gender, sexuality, physical disabilities and species is the same ideology which sanctions the oppression of nature."

Elephas maximus is on the IUCN red list as an endangered species, with habitat loss and degradation cited as the greatest threat to wild populations (Choudhury et al., 2008). Elephant conservation priorities include minimizing human-elephant conflict and preventing the poaching and capture of wild elephants for the live trade as well as the disturbing new trend of killing elephants for their skin (Van de Water and Matteson, 2018; Gosling, 2018). In Thailand, conservation efforts have focused primarily on the fragmented, wild populations living in highly managed national parks (Loahachaiboon, 2010; Van de Water and Matteson, 2018).

Like many other Southeast Asian countries, Thailand has experienced widespread deforestation in the last century, destroying much of the elephants' habitat. In 1961, 53\% of the country's forest was suitable elephant habitat; this has diminished to $32 \%$ according to the most recent statistic from Thailand's forestry department (Permsirivanchai, 2017). In our Anthropocene era of human influence on the environment (Crutzen, 2006), few if any large undisturbed wild elephant populations remain (Ballou et al., 1995). It has consequently been suggested that populations of elephants intensively managed in situ are crucial for the survival of the species (Cameron and Ryan, 2016). In Thailand, largely overlooked by conservation efforts, there already exists a large in-situ elephant population held in 
environments of varying degrees of captivity. One government sponsored project in Thailand has attempted to release captive elephants to the wild. There has as yet been little research on the success of this project and the rehabilitation methods used (Thitaram et al., 2015).

Thailand's current population of legally designated captive elephants is estimated at 30-4500 - more than its wild population of 16-3700 (Kemf, 2000; Sukumar, 2006; Pintavongs et al., 2015). Most captive elephants are used primarily for tourism-related activities, such as elephant rides, performances, and various other interactive experiences (Sukumar, 2006; Nijman, 2014). Most of these elephants live in facilities that are intensively managed to varying degrees. They are often cared for by inexperienced mahouts who do not come from a traditional mahout background in tending elephants. Most elephants are constrained in their movements and the expression of natural behaviors. They spend many hours physically restrained on unsuitable substrate, subsisting on a limited and inadequate diet. They lack regular access to natural foraging, bathing, social interaction, or the possibility of exercising individual choice (Schmidt-Burbach et al., 2015).

In an ideal world, all elephants would be living free, in their natural environments, unfettered by human activity. This ideal seems unachievable in the current state of world affairs, although it should remain an aspirational goal, shaping conservation efforts and values. In Thailand today there are structural limits in place; any discourse about the possibilities for improving elephants' lives must work within these constraints. A major constraint is the fact that captive elephants in Thailand are legally designated as property; they can be traded and are worth large sums of money. Until the structure of ownership and trade changes, we must reckon with the reality that all proposed solutions for elephants have to fit within this legal and economic model.

The deep historical and cultural entanglements between human communities and elephants in Thailand are another key factor in the viability of any conservation efforts. Despite this reality, and the fact that the demand for elephants in elephant tourism is not likely to disappear in the near future, there are ways in which existing entanglements can foster relationships of human/elephant reciprocity in which elephants can thrive. For captive elephants in Thailand, there is significant potential for achieving a state in which elephants are free-living, forage a natural diet, form organic social groups (even with wild conspecifics), and express a full range of behaviors and emotions. Traditional mahout knowledge of elephant husbandry, developed over many generations of working alongside elephants, may provide the missing link for harmonious management of elephants in their native forest.

We are thus proposing a new approach to elephant protection and conservation, with rescue, rehabilitation, and rewilding facilitated by experienced mahout-guardians who understand the needs of individual elephants, their personalities and their life histories. This would be a compassionate model for conservation in the era dominated by humans when being "wild" no longer pertains to status at birth but to providing elephants with the chance of living a life worth living.

\section{Rewilding and being wild}

The concept of "rewilding" takes many different forms. As a scientific term, it has been influenced by the North American Wilderness Recovery Strategy (Wildlands Project of 1991) whose original aim was to create core wilderness areas, free of human activity (U.S. Wilderness Act of 1964; Public Law 88-577). It has often been treated as an ecological 
phenomenon (Jørgensen, 2015; Gammon, 2018) — an attempt to restore lost ecological or evolutionary function to the environment (Donlon et al., 2006), often by trying to reduce the artifacts of past and present human intervention (Lorimer et al., 2015).

The ethical, philosophical, and scientific justifications for critiques of rewilding (Descola and Pálsson, 1996) derive in part from the notion of a land belonging to no one terra nullius - invoked for centuries as legal justification for occupying the land of others, marginalizing indigenous communities (Langton, 1996; Buchan and Heath, 2006). Alienation and annihilation through conservation-motivated rewilding have afflicted other species too. Rewilding projects often assign value to species on the basis of a revisionist ecological history, driven by the winners (e.g., see discourse on Predator Free 2050 Campaign in New Zealand). However, "rewilding as a specific form of ecological restoration does not require human abandonment or erasure of cultural landscapes" (Prior and Brady, 2017). More recent rewilding endeavors have recognized humans as part of nature (e.g., Torres et al., 2018).

Being wild does not pertain solely to living in a wilderness. Wildness must provide individuals with a species-suitable range of challenges, relationships and emotions, an interaction among internal and external factors (Cookson, 2011). Our idea of "rewilding" is to restore autonomous agents to the landscape (Gammon, 2018). We believe that a state of being wild that is meaningful to elephants can be attained in a landscape where both elephant and human cultures are valued.

\section{Historic entanglement of mahouts and elephants in Thailand}

In Thailand, as in all countries in which they range, elephants are culturally and politically significant. They figure prominently in Buddhist religious iconography and as emblems of the Thai Monarchy (Sukumar, 2012). They have also played a key role in Thailand's economy as draught animals in the logging industry and as tools of war in the maintenance of political power (Wylie, 2009).

During the $20^{\text {th }}$ century, elephants had been used in Thailand primarily to assist in felling and transporting lumber across difficult mountainous terrain. Skilled Karen and other Hilltribe mahouts were often sought for this work because of their knowledge of forests and elephants (Wylie, 2009). In the mid-20 th century, it was estimated that 13,000 captive elephants were being used in this industry (Laohachaiboon, 2010). The number of captive elephants dropped significantly toward the end of the century. The Thai department of livestock in 2001 reported the existence of just under 3,000 (Laohachaiboon, 2010). Today, although exact captive population numbers are disputed, estimates hover around 4-5000 for the total number of captive elephants plus only 1,650-3,700 left in the wild (Kemf, 2000; Sukumar, 2006; Pintavongs et al., 2015).

In Thailand, the history of captive elephants is closely linked with the history of mahouts. For as long as elephants have been trained and used in Thailand, there have been mahouts working with them. Traditionally each elephant was cared for by an individual mahout who was often either the owner of the elephant or a relative of the owner (Lair, 1997; Hart, 2000). In the days of logging, mahouts were considered skilled tradespeople, held in high esteem, with the career of mahout passed from one generation to the next, along with the ownership of the family's elephants. Becoming a mahout required many years of apprenticeship before a young man was confident to train and care for an elephant (Lair, 1997). Rapid changes in Thailand's elephant-keeping practices in the past 30 years have 
affected the welfare and conservation of all of Thailand's elephants and have also drastically changed what it means to be a mahout (Lair, 1997; Schmidt-Burbach, 2017; Bansiddhi, 2018).

Today the term mahout is used to refer to anyone who works with elephants; however, many mahouts working in the Thai elephant tourism industry are not experienced with elephant behavior and needs. These titular mahouts have often had no apprenticeship, as had been traditional for previous generations of mahouts, nor any formal training. They instead fall into the role out of economic need or because they are undocumented foreigners (Lair, 2002; Cadigan, 2016). In such cases, it is not uncommon for titular mahouts to be fearful of the elephant to whom they have been assigned. Their lack of experience, together with the exploitative nature of elephant tourism camps, perpetuates physically dangerous conditions for both elephants and humans (Cadigan, 2016.)

The pattern of elephant ownership has also changed, from mahout-owners to what Lair (1997) calls "remote owners," who own and profit from elephants without working directly with them. Godfrey and Kongmuang (2009) report that elephants with remote owners have access to the least amount of natural forage, a key component to elephant health.

The occupation of mahout is now considered one of the lowest jobs in Thai society. Cadigan (2016) interviewed mahouts working in Northern Thailand following the death of their colleague who was killed by a male elephant while working. The mahouts she interviewed discussed the instability of their employment, largely due to their status as illegal immigrants. Cadigan found that mahouts in this region reported working "14-hour days, seven days a week, 365 days a year." Mahouts reported salaries as low as 3-5000 Thai baht (THB) per month, about \$85-142 USD. There has been almost no academic attention paid to the cultural or socioeconomic hardships of mahouts (Hart and Sundar, 2000; Boonmee et al., 2012). Further research in this area is sorely needed because understanding the practices of mahouts, and their ideas about the elephants - historically and currently — is essential for understanding the dynamics of the captive elephant industry.

In Thailand, the practice of using elephants for logging stopped abruptly in 1989 in response to devastating flash floods that destroyed multiple villages and killed 251 people (Delang, 2001). The Thai government attributed these floods to unsustainable logging practices and quickly banned logging in response. Neither elephant welfare nor conservation were the impetus for the ban. The actual cause of the floods remains somewhat disputed, with evidence that rubber tree plantations rather than teak logging might have been the actual culprit (Delang, 2001). Regardless of the cause, the result was the immediate criminalization of the use of elephants in the logging industry, leaving an estimated 2000 mahout-owners suddenly without sources of income, coupled with the huge expense of caring for their elephants (Lohanahan, 2001). Elephants in captivity can consume up to 150 $\mathrm{kg}$ of food per day, which becomes an intractable expense when mahouts are unemployed. When logging, elephants had access to a wide array of natural forage in the forest, but with the practice banned, mahouts largely needed to grow or purchase enough food to feed their elephants. In addition to the mahouts' loss of income, the Forest Industry Organization (FIO) of the Thai government suffered a catastrophic drop in its annual income from the logging industry. The drop was from 293 million THB per annum before the ban to 36 million THB the following year (Laochachaiboon, 2010).

The years immediately following the 1989 logging ban became desperate times for many former-logging mahouts. Consequently, the practice of bringing elephants into the cities and other tourism centers became common as a means of income (Pimmanrojnagool, 
2001). This practice proved dangerous for mahouts, elephants, and city dwellers, resulting in a poor quality of life for elephants. This practice was ultimately banned in 2010.

The need for sustainable solutions for mahouts and their elephants was a focus of the first United Nations Forest and Agriculture Organization conference on Asian elephants in 2001 (Baker and Kashio, 2002). At this conference the issues of elephant conservation and poor elephant welfare were described as a consequence of "unemployed" elephants, in the new, post-logging economy. Vehicular accidents, malnutrition, and infectious disease were listed as key threats elephants faced due to a lack of suitable employment opportunities (Ratanakorn, 2001).

In the years immediately following the logging ban, FIO explored ways to monetize the captive elephant population, including the development of an elephant show and riding tourism initiative at the Thai Elephant Conservation Center (TECC) in Lampang. Laochachaiboon (2010) shows that the TECC's practices of elephant conservation were financially oriented and that as a result, the profitable elephant tourism programs became a priority over the initial stated goals of the TECC, which included mahout training programs, reforestation and habitat protection. Despite leading the way in new sources of income for mahouts, TECC could not possibly employ all of the 2,000 unemployed mahouts. Instead, TECC's tourism model, consisting of elephant rides and circus-style elephant shows was adopted by a number of private businesses forming what would become the highly profitable elephant tourism industry that exists today. By 2001, 948 elephants were being used for "ecotourism" across all regions of Thailand, the majority in the North; Tipprasert (2001) asserted that continuing to develop ecotourism as a suitable employment opportunity for all mahouts was a sound course of action, but added that a comprehensive development plan needed to be created to ensure, among other concerns, adequate welfare and working conditions. Such a plan was never enacted, and the industry has since experienced nearly unchecked growth, utilizing most of the captive elephants and mahouts in Thailand.

Traditional mahouts with generations of situated elephant knowledge are integral to rewilding. Elephant conservation efforts need to include these Karen hilltribe and other traditional mahout communities. Karen communities have a long tradition of elephant keeping and forest protection; they have also advocated successfully for forest rights in Thailand (Kunlawadi, 1997). According to Johnson and Forsyth (2002), "the Karen are perhaps the most well-recorded example of a hill tribe successfully negotiating access rights to forest areas within community-based negotiation." Many hundreds - if not thousands of Asian elephants are currently owned by Karen families in Thailand. Karen people have used elephants for a variety of activities, specifically, logging and as a beast of burden in agriculture. Anecdotal records suggest that when not working, Karen mahouts traditionally brought elephants back to the forest, where the elephants would reunite with their families. Once logging was banned and transportation and agricultural technologies advanced, many Karen mahouts were pressured economically to turn to the burgeoning elephant tourism industry for their income. Not only did this force elephants into a more intensive captive life, but the mahouts were forced in most cases to leave their homes to work in the tourist camps. In many Karen villages, as the elephants left for the camps, large tracts of their forests were converted to crops such as corn. 


\section{Species membership}

Thailand's elephants have been categorized by most authors as two entirely distinct, disconnected populations: "wild and endangered" versus "captive (domesticated) and unemployed" (Lair, 1997; Baker and Kashio, 2002; Bansiddhi, 2018). The UN FAO defines a "domesticated" elephant as "an elephant that is captured from the wild and tamed, or its offspring if not selectively bred" (Baker and Kashio, 2002). This is a departure from the accepted scientific model of domestication, which is a descriptor for a population that has been selectively bred over many generations, passing down desired traits until the domesticated population differs from the wild population in some significant, scientifically measurable way (Price, 1984; Zeder et al., 2004). Lair (1997) argues that "a domesticated elephant is simply a wild elephant in chains," but also posits that the term captive is overly emotional and inaccurate when referring to elephants that have been bred in captivity. In the opening address to the FAO conference, Singh (2001) stated that the "domesticated Asian elephant receives much less global attention than its wild counterpart even though the animal is one and the same species."

Referring to captive elephants as a domesticated population, and speaking about them relative to their employment status, effectively normalizes them as inherently working animals. This neglects their ecological and evolutionary dynamics (Child et al., 2019). As megaherbivores, it is not uncommon for Asian elephants to spend up to 18 hours a day foraging on a wide array of naturally growing plants, a fact incompatible with the current demands on elephants in typical elephant camps, where they are deprived of access to foraging and are on a schedule to work and perform for tourists throughout the day (Sukumar, 1990).

An instrumental view centered on the human employment of elephants situates them in the human-domestic sphere, excluding concerns about wildness. To discuss captive elephants in terms of human labor codes and issues is to ignore their species-specific needs and impose human notions of success and value on them. This anthropocentric view then seeps into the mainstream media. In a New York Times article on working elephants in Myanmar (Fuller, 2016), the author described a good life for elephants as including "eighthour work days, five days a week, retirement at 55, mandatory maternity leave, summer vacations and good medical care."

Ironically, as more elephant owners are absentee (remote owners), the instrumental view also casts mahouts as caregivers, rather than employees, thereby excluding them from discussions of human labor in the elephant tourism industry. The voices of employed mahouts are rarely heard; their precarious employment circumstances make speaking out almost impossible (Cadigan, 2016). This labor dynamic has been studied in depth in other fields. A comprehensive study of the representation of domestic laborers in the International Labor Organization (ILO) shows that conflating domestic laborers with caregivers - often referred to as "part of the family" by their employers - excludes them from the ILO and opens them to be exploitation (Boris and Fish, 2014).

To describe elephants living in captive environments who have not undergone the process of domestication, we consider the accurate term to be "captive." Moreover, it represents a legal status, distinct from that of their wild counterparts, with real-world implications regarding what treatment is permissible. Wild elephants, unlike their captive counterparts, are considered an endangered species in need of protection from human 
disturbance and conflict. In 1992 the Thai government passed the Wild Animal Reservation and Protection Act (WARPA). WARPA officially defined wild elephants as an endangered species and banned their killing or capture and the trade in their parts (Wild Animal Reservation and Protection Act, 1992). National parks were created to try to ensure there would be sustainable elephant habitat. Once an elephant is poached from the wild environment, however, they no longer fall under the protection of WARPA and are instead considered beasts of burden according to the 1939 Draught Animal Act - DAA (or Beasts of Burden Act). The DAA covers the sale and trade in elephants as livestock, but does not refer to their welfare. ${ }^{1}$ Until 2016, a provision of the 1939 DAA allowed captive elephants to be kept legally unregistered by owners until the elephant reached 8 years old, allowing for the laundering of many wild caught elephants into the elephant trade (Nijman, 2014). This major loophole was remedied in 2016 with the creation of a new DNA database for captive elephants and tightening regulations on elephant registration (Nijman, 2014; SchmidtBurbach, 2017).

\section{Elephant welfare and wellbeing}

In 2014, Thailand passed the Cruelty Prevention and Welfare of Animal Act, the first act to address welfare in captive and domesticated animals in Thailand. It defines cruelty as "an act or a failure to act which causes an animal to suffer, physically or mentally, or causes an animal to suffer from pain, illness [or infirmity] or may cause death to such animal" (Cruelty Prevention and Welfare of Animal Act, 2014). Under this broad definition, many aspects of the current elephant tourism industry would be illegal.

In the 1990s, few formal elephant tourism ventures existed. At the time, most mahouts were still trying to earn an income either from illegal elephant-logging or from the selfdriven, unsystematised practice of elephant street begging, which involved bringing elephants to crowded city centers and charging tourists to feed and pose with the elephants. Street begging was universally condemned in the early 1990s and subsequently banned in Bangkok and Chiang Mai. In part as a solution to the issue of street-begging elephants, an organized and more systematized elephant tourism industry was proposed. The potential scope and ramifications of an elephant tourism industry, however, and the resultant financial value of owning and utilizing elephants to earn profits, were not fully considered in advance (Laohachaiboon, 2010; Pimmanrojnagool and Wanghongsa, 2010). Today, the elephant tourism industry is well-established and highly profitable. Since the 1989 logging ban, the number of elephants in captivity has more than doubled. The proportion captured from the wild is uncertain, hence their status and numbers are unconfirmed. Multiple authors have pointed out that the low birth rate of elephants in captivity coupled with the industry demand has incentivized the poaching of wild elephants, particularly from across the Myanmar border (Godfrey and Kongmuang, 2009; Nijman, 2014). Most former logging elephants have died in the 30 years since the logging ban, which suggests that the tourism industry has become a primary driver for the growing captive population (Schmidt-Burbach, 2017).

\footnotetext{
${ }^{1}$ The Draught animal act is cited in all scholarship on elephants in Thailand. The act was previously published on Thailand's Department of Livestock Development web page but has recently been removed, possibly because of a petition for the country to change the act within the last year. A new animal husbandry bill now appears to have been proposed and is listed as open to public comment, possibly indicating plans to update the 1939 law.
} 
The issues surrounding captive elephants have dramatically shifted because of the explosion of the elephant tourism industry. The monetary value of elephants has skyrocketed, both for elephant owners who work as mahouts and those who rent or sell them to elephant-tourism camps. Between 1998 and 2013, the price of a captive elephant in Thailand increased three-fold to more than \$30,000 USD; more recent sales indicate that the price has since doubled. Meanwhile, the fine for poaching a wild elephant is only $4 \%$ of the value of an elephant on the current market (Nijman, 2014).

Experts agree that there are large welfare and conservation concerns in the current state of the industry, but they often disagree on the specific concerns, and on what needs to be done (ASEAN, 2015; Schmidt-Burbach, 2017; Bansiddhi et al., 2018). Some argue that there is no alternative to the elephant tourism camps offering interactive elephant entertainment, claiming that tourist camps "provide the only viable and realistic options for sustaining a captive population and providing employment for mahouts" (Bansiddhi et al., 2018). Others demand an end to all elephant tourism - a perspective that is incompatible with traditional Thai beliefs concerning elephants (Kontogeorgopoulos, 2009a; Duffy and Moore, 2011).

A typical argument made to support the current elephant tourism industry is that discouraging tourists from attending elephant attractions hurts the elephants themselves because increased income at camps leads to better welfare for the elephants (Cadigan, 2016). However, as the popularity of elephant attractions grows, the number of captive elephants continues to rise. A recent welfare assessment of Asian elephants in Thailand shows that although some welfare conditions for tourist elephants have improved, the number who experience the poorest welfare conditions has also increased (Schmidt-Burbach, 2017).

Campaigns to educate tourists and tourism companies on the welfare concerns of elephant camps have been marginally successful. To continue to attract tourists, some camps have shifted from offering elephant riding to opportunities to feed and bathe the elephants. Camps that offer only bathing typically use ecotourism and sustainable tourism buzzwords to attract tourists such as: "sanctuary, elephant care facility, retirement home, jungle park" (Daly, 2019). These terms belie the disadvantaged lives of these elephants. The daily life and schedule of elephants in many "bathing only" camps can be minimally different from the more conventional riding camps. Moreover, diets irregular in both timing and content have led to health issues. For example, the fruit that tourists are given to feed the elephants throughout the day causes insulin spikes (Norkaew, 2019).

Elephant tourism in Thailand has become a prominent issue in the global media. Increasingly polarized discussions of cruelty and abuse often lead to problematic generalizations (see Frazier, 2019). Kim's (2015) work on human-animal issues shows how the narrow focus on a particular aspect of a problem can lead to missing or denying important complexities and nuances. For example, the understandable but insufficient focus of (mostly Western activist) groups on cruelty has obscured the need for a more holistic approach to elephant wellbeing that would call for far more than just eliminating direct cruelty. Free access to natural foraging, space, and social interactions with other elephants is also necessary. The exclusive focus on eliminating direct cruelty has also blurred complex socioeconomic and ecological issues faced by mahouts. This has led to broad vilification of a group of people, and the use of mahouts as scapegoats to hide systemic problems in an industry with too many victims. 
Overall, there is a good deal of secrecy surrounding the conditioning practices for captive Asian elephants in range countries. Consequently, there has been little formal oversight. The lack of documentation and understanding extends to the conditioning practice known as "phajaan" (Weary, 2014). In the media, phajaan is attributed to Southeast Asian mahout cultures and has become a cause célèbre in the fight against the elephant tourism industry. The term phajaan is applied broadly to all kinds of conditioning of young elephants. This indiscriminate use has overshadowed known violations in the elephant tourism industry and has led to further marginalization of indigenous Karen communities.

To reform an exploitative industry, important distinctions need to be understood and taken into account. Cruelty and abuse undeniably occur in the captive elephant world within and beyond Thailand. Animals have been wrested from their homes and families to work and perform for humans; this violence is rooted in the history of elephant captivity. But violence is not the complete picture of this relationship. There is a critical need for ethnographic, historical, and ecological research into the relationships of human communities with elephants - research based on a larger sample than has been observed to date. We have personally witnessed caring relations with elephants in the Karen mahout communities we have observed. Such practices do exist even though they are poorly documented. We believe the evidence of nonviolent relationships with owned elephants has the potential to steer elephant tourism from captivity and exploitation toward returning captive, working elephants to protected forest habitats.

We are advocating an end to the oppression, utilization, and deprivation inflicted on elephants by the tourism industry, but not necessarily an abolitionist stance on elephanthuman relationships. Elephants are complex animals, capable of relationships of reciprocity within and between species. In the current state of affairs, there is a need for mahouts to train and serve as guardians for young elephants born to owned females. This can be done using positive reinforcement training, as with dogs (Pryor, 1999; Berns and Cook, 2016), so as to foster a relationship of trust and communication between elephants and humans (Fagan et al., 2014), helping to teach the life skills needed in mixed communities and to prevent problematic behaviors (Vicino, 2020). To avoid ambiguities and misunderstandings associated with phajaan, we advise against its use by the wider community. Instead, we recommend drawing a clear line between the ethical and practical foundations of the specific methods used to distinguish any form of punishment-driven technique to promote human domination from nonviolent, reward-based conditioning methods to promote a healthy bond.

\section{The path to rewilding and being wild}

Compassionate Conservation (CC) has emerged as a multidisciplinary field dedicated to reforming our relationships with and responsibilities to wild animals. CC has a broad disciplinary scope, but its emergence at the interface of animal welfare science and conservation biology remains formative. A key objective of CC is scientifically and ethically sound conservation practices that value and treat other animals as individuals, with families, neighbors, and culture instead of viewing them as units of populations and species (Bekoff, 2013; Ramp and Bekoff, 2015; Baker, 2017): "[A]ny formulation of what is meant by animal welfare ... has to take into account both the long-term needs and the short-term wants that have evolved in wild animals and are still the legacy of captive ones" (Dawkins, 2012). CC 
seeks to extend this to our conservation practice through rescue, rehabilitation and rewilding.

Elephants are large-brained, socially complex mammals. They evolved their complex cognitive abilities in the context of requiring large quantities of diverse forage, available across vast areas, making captivity an even greater violation of their biological imperatives. Acquiring and communicating information is multi-modal in elephants. Their sensory discrimination across chemical, auditory, and visual modalities is acute (Shoshani et al., 2006; Byrne et al., 2009; de Silva, 2010). Through cultural transmission, passed down across generations, elephants show extensive awareness and knowledge of their environments (Bates et al., 2008; Bradshaw, 2009). In addition to sharing knowledge, elephants show empathy and cooperation (Byrne et al., 2008) and have "mind-reading" capacities (Plotnik and de Waal, 2014; Plotnik et al., 2010, Bates et al., 2008a). These capacities give elephants vast potential for rehabilitation and rewilding (Plotnik, 2016; Bansiddhi, 2018).

Their current legal and conservation status in Thailand is not based on elephants' true conservation potential. In the wild sphere, conservationists fight for increased habitat, reduced human disturbance, and solutions for coexistence. In the captive sphere, animal advocacy organizations fight for access to a more diverse diet, water and shade, medical care, and respite from grueling work conditions. These welfare improvements are all sorely needed, but they still fall short of the opportunities available to wild elephants (SchmidtBurbach, 2017).

Many organizations in Thailand - both those devoted to welfare and those devoted to conservation - fail to address the entanglement of elephant tourism and elephant conservation. Most efforts focus solely on one or the other. Those whose efforts target only wild elephants are ignoring the majority of the elephants in Thailand, who are captive but no less endangered. They are also sidestepping the major threats to wild populations and habitats. Organizations that focus on captive elephant welfare are treating only the symptoms of a much larger problem. Some rescue elephants in the tourism industry by purchasing or renting them, but this just feeds money back into the source of the problem, giving industry stakeholders the resources to expand their captive elephant populations. There is little evidence that the elephant tourism industry has had any positive effect on wild populations and habitat recovery. New models of ecotourism and conservation are desperately needed to counter the negative effects of the conventional model on the demand for captive elephants, the loss of native habitat and the welfare issues facing captive elephants.

Captive elephants retain the capacity to live in an environment in which they can make decisions for themselves, forage their own food, and form their own social groups (Miththapala, 2009; Thitaram et al., 2015). In 1997, Thailand's Queen Sirikit initiated a project to release captive-raised elephants into wildlife sanctuaries and national parks. To date, 104 elephants have been released. Thitaram et al. (2015) report that they have adapted well, forming social groups similar to those observed in other studies on wild elephants. Miththapala (2009) documents similar outcomes with elephant calves rehabilitated at Elephant Transit Home in Sri Lanka; they reintegrate into wild herds there.

Wildlife rehabilitation is not usually thought of as a conservation tool, because it tends to be concerned with rehabilitating individual animals, whether abundant or rare, rather than species (Aitken, 2004). Rehabilitation, however, and the knowledge of skilled rehabilitators, are crucial to protecting disadvantaged wildlife, and hence to safeguarding nature and promoting wildness. Aitken (2004) describes "disadvantaged" animals as those 
who are suspected of being in imminent danger of dying, whose lives are under threat, or whose quality of life is seriously compromised. Disadvantage can occur through illness, incapacity, dispossession, and orphaning. Many captive elephants are undeniably disadvantaged in these ways.

Our hypothesis is that in addition to restoring individual wellbeing, rehabilitation will be an important aid in rewilding elephants and bolstering the health of elephant populations. Many elephants rescued from captivity will need considerable rehabilitation before they can be successfully rewilded. For particularly disadvantaged individuals, rehabilitation efforts will require considerable, meticulous planning to rebuild their cognitive, behavioral, and physical skills and prevent any welfare problems from arising after rewilding. For captive elephants coming from intensively managed facilities, rehabilitation - informed by the knowledge and skills of mahout communities, such as certain Karen hilltribe mahouts - can be an important part of the rewilding process.

Most of the studies on Asian elephants, including welfare assessments, have taken place in captive environments, providing a limited view of elephant behavior, with minimal evolutionary and ecological context. Many researchers use captive populations as direct models for understanding the behavior and cognition of wild elephants (Irie and Hasegawa, 2009; Whilde 2012; Stoeger et al., 2012; Plotnik and de Waal, 2014). In Thailand, the efforts of a few conservation and elephant welfare organizations to rewild captive elephants (including the rewilding project we are involved in) present a unique research opportunity, with important implications for improving elephant lives and providing a richer understanding of the species (Stroud, 2007). Such projects can also help identify important political, social, cultural and legal factors that might facilitate the enduring protection of Asian elephants in range countries.

Elephants in Thailand who have spent much of their lives forced to work and perform at elephant tourism camps have been successfully rewilded into managed forests by NGOs (including Mahouts Elephant Foundation, the organization with which we are involved) through Asian elephant protection projects. This has been accomplished by trying to create alternative models for elephant protection and tourism through collaboration with Karen communities who own captive elephants. Every captive elephant in Thailand is owned and subject to the 1939 draught animal law. It is further required that all captive elephants be DNA tested once in their lives and examined by a veterinarian annually (Fletcher, 2016). All elephants legally designated as captive are still subject to these laws and still entangled in relationships with human communities, but it is these relationships that make possible the levels of autonomy and agency that these rewilded elephants can achieve. In these communities, the elephants can have access to thousands or hundreds of thousands of acres of native habitat, minimizing human-elephant conflicts.

The Rescue/Rehabilitate/Rewild ("3R") model addresses many of the factors that have led to the decline and loss of habitat of Asian elephant populations in Thailand. As described above, socioeconomic circumstances in Thailand have compelled Karen mahouts to leave their villages with their elephants to work in elephant tourism camps. This exodus has led to increased deforestation in order to grow cash crops. Many Karen communities have forest-management, grazing and agricultural rights in large areas of state-owned forests; thus, in those Karen-managed forests where elephants have been rewilded, there is increased opportunity to shift away from habitat-degrading agricultural practices, allowing habitat to be restored. The model is designed to alleviate the monetary pressure to convert native 
habitat to agriculture. It curtails the need to parcel up land, by assisting with the return of elephants - who are key seed dispersers - to forest land (Puri et al., 2019). The 3R model thus offers an economically and ecologically viable alternative.

Rewilding can provide sustainable cultural and economic stability, providing mahouts and their families with an alternative income that can reduce reliance on the agricultural practices that have destroyed elephant habitats. Mahouts who left home to work in the elephant camps can integrate again into village life with family and friends. With the transition of the elephants from tourist camps to the forest, the mahouts return to more traditional roles as elephant and forest guardians. The Karen mahouts patrol the forest and monitor elephant movement, reducing human-elephant conflicts. Karen mahouts develop ecotourism in their communities, guiding ecotourists into the forest habitat to observe the elephants unobtrusively. The 3R model brings the economic benefits back to those rural communities that coexist with elephants.

Preliminary rewilding efforts seem to be showing that elephants, including those who had been working in intensively managed camps, can learn to navigate space and terrain, to forage for themselves on a host of native plant species, and to form natural social groupings, facilitated by the guardianship of experienced, knowledgeable Karen mahouts. The behavioural repertoire and activity budgets of rewilded elephants seem to be similar to those of their wild counterparts; stereotypic behaviors born of captivity and restricted space and activity begin to abate. Rewilded elephants' communication behaviors, foraging ecology, social dynamics, resource needs, habitat carrying-capacity, and use of space are all ripe for research.

Because Asian elephant habitat can conflict with human economic priorities, community development concerns must be integrated into wildlife conservation measures to ensure long-term sustainability (Zhang et al., 2006). In Thailand, there are pockets of forest that may very well serve as suitable habitat for smaller populations of rewilded elephants. The home range size for Asian elephants has been estimated to exceed $100 \mathrm{~km}^{2}$; however, only $29.01 \mathrm{~km}^{2}$ of optimal or suitable elephant habitat exists in a small portion of Nangunhe Nature reserve, home to 18-23 wild Asian elephants (Jathanna et al., 2015; Peng et al., 2016). Peng et al. also suggest that rewilded individuals could contribute to the genetic diversity of small, isolated wild populations.

\section{Conclusion}

In the current conservation crisis, we are faced with the challenge of trying to restore the capacity of being wild to disadvantaged animals - both those in captivity and those living in a compromised wild habitat. The captive Asian elephants in range countries represent a possibility for novel conservation efforts to restore their abilities to navigate new terrain and experiences, form new social bonds, and integrate into the wild population at large.

The conservation efforts that are the most likely to be successful are those recognizing that the wellbeing of humans and of other animals in the Anthropocene are inextricably intertwined (Bennett et al., 2017). In Thailand, rewilding projects have the potential to restore native elephant habitat while also supporting local culture and livelihoods. Traditional mahouts and the situated knowledge of mahout communities are critical to understanding and implementing a way for human and elephant communities to coexist. Karen mahouts should hence be offered leadership roles in local conservation projects. 
Conservation priorities need to reflect the threats faced by the entire species Elephas maximus, captive and free. Species status reports should encompass both. Funding and research should be directed toward a better understanding of the rewilding process, covering not only the ecological, behavioral and psychological needs of transitioning animals but the knowledge and the needs of local human communities.

Acknowledgements: We thank three anonymous reviewers and the journal editor for their invaluable suggestions. We are grateful to S. Blaine and F. Blaine for their insight and contribution to this manuscript. We thank E. Massiot, C. Greer, M. Babola, and M. van Maarschalkerweerd for assistance in the field. We are grateful for the collaboration with HPCCG and KPD.

\section{References}

Aitken, G. (2004). A new approach to conservation: The importance of the individual through wildlife rehabilitation. Ashgate Publishing, UK.

Ambrose, D. (2015). Tourist dollars feed wild animal trade in Thailand. Aljazeera.com.

Anan, G. (2000). Local control of land and forest: Cultural dimensions of resource management in Northern Thailand. Chiang Mai: Chiang Mai University.

Angkavanish, T., and Thitaram, C. (2012). Behavioral study and monitoring of Asian Elephant (Elephas maximus) reintroduction under the Queen's initiative. In M. Aranovich and O. Dufresne (Eds.), Elephants: Ecology, behavior and conservation. Animal science, issues and professions. Nova Science Pub Inc; UK ed.

ASEAN Captive Elephant Working Group. (2015). Addressing a giant problem in Southeast Asia.

Baker, I., and Kashio, M. (2002). Giants on our hands: Proceedings of the International Workshop on the Domesticated Asian Elephant. Bangkok, Thailand: Food and Agriculture Organization of the United Nations, Regional Office for Asia and the Pacific.

Baker, L. (2017). Translocation biology and the clear case for compassionate conservation. Israel Journal of Ecology and Evolution 63, 52-60.

Ballou, J.D., Gilpin, M.E., and Foose, T.J. (1995). Population management for survival and recovery: Analytical methods and strategies in small population conservation. Columbia University Press.

Bansiddhi, P., Brown, J.L., Thitaram, C., Punyapornwithaya, V., Somgird, C., Edwards, K.L., and Nganvongpanit, K. (2018). Changing trends in elephant camp management in northern Thailand and implications for welfare. PeerJ 6, e5996.

Bates, L., Lee, P.C., Njiraini, N., Poole, J., Sayialel, K., Sayialel, S., Moss, C.J., and Byrne, R.W. (2008). Do elephants show empathy? Journal of Consciousness Studies 15, 204-225.

Bekoff, M. (Ed.). (2013). Ignoring nature no more: The case for compassionate conservation. University of Chicago Press.

Bekoff, M., and Pierce, J. (2017). The animals' agenda: Freedom, compassion, and coexistence in the age of humans. Beacon Press, Boston

Bennett, N., Roth, R., Klain, S.C., Chan, K., Christie, P., Clark, D.A., Cullman, G., et al. (2017). Conservation social science: Understanding and integrating human dimensions to improve conservation. Biological Conservation 205, 93-108.

Berns, G.S., and Cook, P.F. (2016). Why did the dog walk into the MRI? Current Directions in Psychological Science 25:5, 363-369. 
Boonmee, S., Chanawongse, K., Uttisaen, U., and Rewdang, K. (2012). Taboo and health behavior of mahout in elephant biosphere of Thailand and Lao People's Democratic Republic. Mediterranean Journal of Social Sciences 3, 369-374.

Boris, E., and Fish, J.N. (2014). "Slaves no more": Making global labor standards for domestic workers. Feminist Studies 40, 411-443.

Buchan, B., and Heath, M. (2006). Savagery and civilization: From terra nullius to the tide of history. Ethnicities 6:1, 5-26.

Byrne, R.W., Bates, L., and Moss, C.J. (2009). Elephant cognition in primate perspective. Comparative Cognition \& Behavior Reviews 4, 65-79.

Byrne, R.W., Lee, P.C., Njiraini, N., Poole, J.H., Sayialel, K., Sayialel, S., Bates, L.A., and Moss, C.J. (2008). Do elephants show empathy? Journal of Consciousness Studies 15:10-11, 204225.

Cadigan, H. (2016). The human cost of elephant tourism. The Atlantic. May 19.

Cameron, E.Z., and Ryan, S.J. (2016). Welfare at multiple scales: Importance of zoo elephant population welfare in a world of declining wild populations. PLoS ONE 11:7, e0158701.

Campos-Arceiz, A. (2016). What should we do about the 15,000 Asian elephants still in captivity? The Conversation.

Chen, J., Xiaobao, D., Ling, Z., and Zhilin, B. (2006). Diet composition and foraging ecology of Asian Elephants in Shangyong, Xishuangbanna, China. Acta Ecologica Sinica 26:2, 309316.

Child, M.F., Selier, S.A.J., Radloff, F.G.T., Taylor, W.A., Hoffmann, M., Nel, L., Power, J., Birss, C., Okes, N.C., Peel, M.J., Mallon, D., and Davies-Mostert, H. (2019). A framework to measure the wildness of managed large vertebrate populations. Conservation Biology 33:5, 11061119.

Choudhury, A., Lahiri Choudhury, D.K., Duckworth, J.W., Easa, P.S., Johnsingh, A.J.T., Fernando, P., Hedges, S., Gunawardena, M., Kurt, F., Karanth, U., et al. (2008). Asian Elephant: Elephas maximus. International Union for Conservation of Nature, Asian Elephant Specialist Group.

Cohen, E. (2008). Explorations in Thai tourism. Emerald: Bingley, 135-178.

Cohen, E. (2015). Young elephants in Thai Tourism: A fatal attraction. In K. Markwell (Ed.), Animals and tourism: Understanding diverse relationships ( $1^{\text {st }} \mathrm{ed}$.). Bristol: Channel View Publications, 163-177.

Cookson, L.J. (2011). A definition of wildness. Ecopsychology 3, 187-193.

Cruelty Prevention and Welfare of Animal Act, B.E. 2557. (2014). Ministry of Agricultural and Cooperatives. Department of Livestock Development. Translated by Legal Opinion and Translation Section, Foreign Law Bureau, Office of the Council of State of Thailand.

Crutzen, P.J. (2006). The "anthropocene". In E. Ehlers and T. Krafft (Eds.), Earth system science in the Anthropocene. Springer, 13-18.

Daly, N. (2019). Suffering unseen: The dark truth behind wildlife tourism. National Geographic Magazine, June.

Dawkins, M.S. (2012). Why animals matter: Animal consciousness, animal welfare, and human well-being. Oxford University Press, UK.

Delang, C.O. (2002). Deforestation in Northern Thailand: The result of Hmong farming practices or Thai development strategies? Society \& Natural Resources 15:6, 483-501.

Descola, D., and Pásllon, G. (1996). Nature and society: Anthropological perspectives. Routledge, London. 
Donlan, C.J., Berger, J., Bock, C.E., Bock, J.H., Burney, D.A., Estes, J.A., Foreman, D., Martin, P.S., Roemer, G.W., Smith, F.A., Soulé, M.E., and Greene, H.W. (2006). Pleistocene rewilding: An optimistic agenda for twenty-first century conservation. The American Naturalist $168,660-681$.

Duffy, R., and Moore, L. (2011). Global regulations and local practices: The politics and governance of animal welfare in elephant tourism. Journal of Sustainable Tourism 19:45, 589-604.

Fagan, A., Acharya, N., \& Kaufman, G.E. (2014). Positive reinforcement training for a trunk wash in Nepal's working elephants: Demonstrating alternatives to traditional elephant training techniques. Journal of Applied Animal Welfare Science 17:2, 83-97.

Fletcher, D. (2016). Elephants in Thailand to have DNA registered. The Independent, October 5.

Frazier, D. (2019). In Thailand, you can ride an elephant. But should you? The New York Times, June 19.

Gaard, G. (Ed.). (1993). Ecofeminism: Women, animals, nature. Philadelphia, PA: Temple University Press.

Gammon, A.R. (2018). The many meanings of rewilding: An introduction and the case for a broad conceptualisation. Environmental Values 27, 331-350.

Godfrey, A., and Kongmuang, C. (2009). Distribution, demography and basic husbandry of the Asian Elephant in the tourism industry in northern Thailand. Gajah 30, 13-18.

Graeme, S., Slotow, R., Durant, S., Sayialel, K., Poole, J., Moss, C., and McComb, K. (October 23, 2013). Effects of social disruption in elephants persist decades after culling. Frontiers in Zoology 10:1, 62.

Hart, L., and Sundar. (2000). Family traditions for mahouts of Asian Elephants. Anthrozoös 13:1, 34-42.

Hart, L., Hart, L.A., McCoy, M., and Sarath, C.R. (2001). Cognitive behaviour in Asian Elephants: Use and modification of branches for fly switching. Animal Behaviour 62, 839-847.

Irie, N., and Hasegawa, T., (2009). Elephant psychology: What we know and what we would like to know. Japanese Psychological Research 51:3, 177-181.

Jathanna, D., Karanth, K.U., Kumar, N.S., Karanth, K.K., and Goswami, V.R. (2015). Patterns and determinants of habitat occupancy by the Asian elephant in the Western Ghats of Karnataka, India. PLoS ONE.

Johnson, C., and Forsyth, T. (2002). In the eyes of the state: Negotiating a "Rights-Based Approach" to forest conservation in Thailand. World Development 30:9, 1591-1605.

Jørgensen, D. (2015). Rethinking rewilding. Geoforum 65, 482-488.

Kemf, E., and Santiapillai, C. (2000). Asian Elephants in the wild: A WWF species status report. Gland, Switzerland: WWF.

Kim, C. J. (2015). Dangerous crossings: Race, species, and nature in a multicultural age. New York, NY: Cambridge University Press.

Kontogeorgopoulos, N. (2009a). The role of tourism in elephant welfare in Northern Thailand. Journal of Tourism 10:2, 1-19.

Kontogeorgopoulos, N. (2009b). Wildlife tourism in semi-captive settings: A case study of elephant camps in northern Thailand. Current Issues in Tourism (online) 12:5-6, 429449. 
Kontogeorgopoulos, N. (2017). Tourism in Thailand: Growth, Diversification, and Political Upheaval. In C.M. Hall and S. Page (Eds.), The Routledge handbook of tourism in Asia. Abingdon: Routledge, 149-163.

Kunlawadi B. (1997). Collective resource management: Mechanisms for forest protection in the Karen village of Sanephong (Kanchatkan sapphayakon suan ruam: Konkai nai kanraksa pa khong chao kariang ban Sanephong). Niwet 24:3, 19-31.

La, B., Lee, P.C., Njiraini, N., Poole, J.H., Sayialel, K., Sayialel, S., Moss, C.J., and Byrne, R.W. (2008). Do elephants show empathy? Journal of Consciousness Studies 15:10-11, 204225.

Lair, R., (1997). Gone astray. Bangkok, Thailand: FAO Regional Office for Asia and the Pacific.

Langton, M. (1995). What do we mean by wilderness?: Wilderness and terra nullius in Australian art (Address to The Sydney Institute on 12 October 1995.) The Sydney Papers 8:1, 10-31.

Laohachaiboon, S. (2010). Conservation for whom? Elephant conservation and elephant conservationists in Thailand. Southeast Asian Studies 48:1, 74-95.

Lin, T. (2012). Cross-platform framing and cross-cultural adaptation: Examining elephant conservation in Thailand. Environmental Communication 6:2, 193-211.

Lohanahan, R. (2001). The Elephant Situation in Thailand and a Plea for Co-Operation. In I. Baker and M. Kashio (Eds.), Giants on our hands: Proceedings of the International Workshop on the Domesticated Asian Elephant. Bangkok, Thailand: Food and Agriculture Organization of the United Nations, Regional Office for Asia and the Pacific.

Lorimer, J., Sandom, C., Jepson, P., Doughty, C., Barua, M., and Kirby, K.J. (2015). Rewilding: Science, practice, and politics. Annual Review of Environment and Resources 40:1, 3962.

Mason, G.J. (2010). Species differences in responses to captivity: Stress, welfare, and the comparative method. Trends in Ecology and Evolution 25, 713-721.

Maurer, G., Rashford., B.S., Chanthavong, V., Mulot, B., and Gimenez, O. (2017). Wild-captive interactions and economics drive dynamics of Asian elephants in Laos. Scientific Reports 7, 1-11.

Miththapala, S. (2009). The Uda Walawe Elephant Transit Home - another opportunity missed? Gajah 30, 24-28.

Nijman, V. (2014). An assessment of the live elephant trade in Thailand. Cambridge: TRAFFIC, $1-38$.

Norkaew, T., Brown, J.L., Thitaram, C., Bansiddhi, P., Somgird, C., Punyapornwithaya, V., Punturee, K., Vongchan, P., and Khonmee, J. (2019). Associations among tourist camp management, high and low tourist seasons, and welfare factors in female Asian elephants in Thailand. PLoS ONE 14:6, e0218579.

Peng, L., Wen, H., Lin, L., Liu, J., and Zhang, L. (2016). Habitat evaluation for Asian Elephants (Elephas maximus) in Lincang: Conservation planning for an extremely small population of elephants in China. Biological Conservation 198, 113-121.

Permsirivanchai, J. (2017). Forest area of Thailand, 1973 - 2016. Forest Land Management Bureau, Royal Forestry Department of Thailand.

Pimmanrojnagool, V., and Wanghongsa, S. (2001). A study of street wandering elephants in Bangkok and the socio-economic life of their mahouts. In I. Baker and M. Kashio (Eds.), Giants on our hands: Proceedings of the International Workshop on the 
Domesticated Asian Elephant. Bangkok, Thailand: Food and Agriculture Organization of the United Nations, Regional Office for Asia and the Pacific, 34-42.

Pintavongs, W., Chueplaivej, P., Boonyasart, B., Kidyhoo, S., Pravai, W., Rattanakunuprakarn, J., Ounsiri, S., Lorsanyaluck, B., Sunyathitiseree, P., Jittapalapong, S., Wajjwalku, W., and Thongtip, N. (2014). Domestic elephant population structure and health status in Thailand. Journal of Kasetsart Veterinarians 24, 16-24.

Plotnik, M., and de Waal, F. (2014). Extraordinary elephant perception. Proceedings of the National Academy of Sciences 111:14, 5071-5072.

Price, E.O. (1984). Behavioral aspects of animal domestication. The Quarterly Review of Biology 59:1, 1-32.

Prior, J., and Brady, E. (2017). Environmental aesthetics and rewilding. Environmental Values 26:1, 31-51.

Pryor, K. (1999). Don't shoot the dog! The new art of teaching and training. Revised ed., Bantam.

Puri, K., Yadav, V., and Joshi, R. (2019). Functional role of elephants in maintaining forest ecosystem and biodiversity: Lessons from northwestern elephant range in India. Asian Journal of Environment and Ecology 9:2, 1-8.

Ramp, D., and Bekoff, M. (2015). Compassion as a practical and evolved ethic for conservation. BioScience 65, 323-327.

Ratanakorn, P. (2001). The role of NGOs in the management of domesticated elephants in Thailand. In I. Baker and M. Kashio (Eds.) (2002), Giants on our hands: Proceedings of the International Workshop on the Domesticated Asian Elephant. Bangkok, Thailand: Food and Agriculture Organization of the United Nations, Regional Office for Asia and the Pacific.

Russell, N. (2002). The wild side of animal domestication. Society \& Animals 10:3, 285-302.

Schmidt-Burbach, J., Ronfot, D., and Srisangiam. R. (2015). Asian Elephant (Elephas maximus), pig-tailed macaque (Macaca nemestrina) and tiger (Panthera tigris) populations at tourism venues in Thailand and aspects of their welfare. PLoS ONE.

Schmidt-Burbach, J. (2017). Taken for a ride: The conditions for elephants used in tourism in Asia. World Animal Protection (WAP).

Shoshani, J., Kupsky, W.J., and Marchant, G.H. (2006). Elephant brain. Brain Research Bulletin 70, 124-157.

de Silva, S. (2010). Acoustic communication in the Asian elephant (Elephas maximus). Behaviour 147:7, 825-852.

Singh, R.B. (2001). Opening address. In I. Baker and M. Kashio (Eds.) (2002), Giants on our hands: Proceedings of the International Workshop on the Domesticated Asian Elephant. Bangkok, Thailand: Food and Agriculture Organization of the United Nations, Regional Office for Asia and the Pacific, 34-42.

Spinka, M., and Wemesfelder, F. (2011). Environmental challenge and animal agency in animal welfare, $2^{\text {nd }}$ ed. (Eds. M.C. Appleby, B.O. Hughes, and J. Mench). CABI, 27-43.

Stoeger, A.S., Mietchen, D., Oh, S., de Silva, S., Herbst, C.T., Kwon, S., and Tecumseh Fitch, W. (2012). An Asian Elephant imitates human speech. Current Biology 22:22, 2144-2148.

Stroud, P. Defining issues of space in zoos. (2007). Journal of Veterinary Behavior 2, 219222.

Sukumar, R. (1990). Ecology of the Asian elephant in southern India. II. Feeding habits and crop raiding patterns. Journal of Tropical Ecology 6:1, 33-53. 
Sukumar, R. (2003). The living elephants: Evolutionary ecology, behavior, and conservation. New York: Oxford University Press.

Sukumar, R. (2006). A brief review of the status, distribution and biology of wild Asian Elephants (Elephas maximus). International Zoo Yearbook 40:1, 1-8.

Sukumar, R. (2012). The story of Asia's elephants. Mumbai: Marg Foundation.

Thitaram, C., Dejchaisri, S., Somgird, C., Angkawanish, T., Brown, J., Phumphuay, R., Chomdech, S., and Kangwanpong, S. (2015). Social group formation and genetic relatedness in reintroduced Asian Elephants (Elephas maximus) in Thailand. Applied Animal Behaviour Science 172, 52-57.

Tipprasert, P. (2001). Elephants and ecotourism in Thailand. In I. Baker and M. Kashio (Eds.) (2002), Giants on our hands: Proceedings of the International Workshop on the Domesticated Asian Elephant. Bangkok, Thailand: Food and Agriculture Organization of the United Nations, Regional Office for Asia and the Pacific, 157-171.

Torres, A., Fernández, N., Zu Ermgassen, S., Helmer, W., Revilla, E., Saavedra, D., Perino, A., Mimet, A., Rey-Benayas, J.M., Selva, N., Schepers, F., Svenning, J-C., and Pereira, H.M. (2018). Measuring rewilding progress. Philosophical Transactions of the Royal Society B 373:1761, 20170433.

Vicino, G.A. (2020). Box B1: Elephant training in zoos. In V.A. Melfi, N.R. Dorey, and S.J. Ward (Eds.), Zoo animal learning and training. Wiley, 183-186.

Walker, A. (2001). The "Karen consensus," ethnic politics and resource-use legitimacy in Northern Thailand. Asian Ethnicity 2:2, 145-162.

van de Water, A., and Matteson, K. (2018). Human-elephant conflict in western Thailand: Socio-economic drivers and potential mitigation strategies. PLoS ONE 13, e0194736.

Weary, D.M. (2014). What is suffering in animals. Dilemmas in animal welfare (M.C. Appleby, D.M. Weary, and P. Sandøe, Eds.). 188-202.

Whilde, J., and Marples, N. (2012). Effect of a birth on the behavior of a family group of Asian Elephants (Elephas Maximus) at Dublin Zoo. Zoo Biology 31:4, 442-452.

Wild Animal Reservation and Protection Act B.E. 2535. (1992).

Wylie, D. (2009). Elephant. Reaktion Books, Limited.

Young, I.M. (2004). Situated knowledge and democratic discussions. In J. Andersen and B.

Siim (Eds.), The politics of inclusion and empowerment. Palgrave Macmillan, London.

Zeder, M.A., Emshwiller, E., Smith, B.D., and Bradley, D.G. (2006). Documenting domestication: The intersection of genetics and archaeology. Trends in Genetics 22, 139-155.

Zhang, L., Ma, L.C., and Feng, L.M. (2006). New challenges facing traditional nature reserves: Asian elephant (Elephas maximus) conservation in China. Integrative Zoology 1, 179187.

Zoological Society London. (2015). Thailand elephant conservation: Mitigating humanelephant conflicts.

Call for Commentary: Animal Sentience publishes Open Peer Commentary on all accepted target articles. Target articles are peer-reviewed. Commentaries are editorially reviewed. There are submitted commentaries as well as invited commentaries. Commentaries appear as soon as they have been reviewed, revised and accepted. Target article authors may respond to their commentaries individually or in a joint response to multiple commentaries.

INSTRUCTIONS FOR COMIMENTATORS 


\section{PhD Scholarship in Foundations of Animal Sentience (ASENT) London School of Economics}

The Foundations of Animal Sentience project (ASENT), a five-year ERC-funded project led by Dr. Jonathan Birch, aims to study the methodological foundations of animal sentience research and the link between sentience and animal welfare. The project seeks to recruit one PhD student. The student will contribute to the project either by exploring the methodological foundations of animal sentience research, or by investigating the pathway from animal sentience research to consequences for animal welfare legislation and policy and/or animal ethics.

The student, at the time of starting the $\mathrm{PhD}$, should have an excellent undergraduate degree and a completed Masters degree in philosophy or another relevant subject, such as comparative psychology, cognitive science, or animal welfare science. The primary supervisor of the $\mathrm{PhD}$ project will be $\mathrm{Dr}$. Jonathan Birch. If you have any questions or want to know more about the project, please write to Jonathan at j.birch2@Ise.ac.uk.

The successful applicant will receive full funding for a 4-year PhD at the LSE, including full payment of tuition fees AND a maintenance stipend of $\mathbf{\$ 1 8 , 0 0 0}$ per annum. To apply, please apply to the MPhil/PhD in Philosophy at the LSE in the usual way, carefully following all the requirements described on the LSE's website: http://www.lse.ac.uk/study-at-lse/Graduate/Degree-programmes-2020/MPhilPhDPhilosophy. When you apply, please indicate clearly in your application (in both your Statement of Academic Purpose AND your Research Proposal) that you wish to be considered for the ASENT scholarship.

You should include, in your research proposal, a substantial description (of at least 1,500 words) of a research project relevant to ASENT. You MAY, if you wish, include TWO research proposals in the same document: a proposal relevant to ASENT, and a proposal on a different subject that you would pursue if awarded an LSE Studentship or a LAHP (AHRC) scholarship. If you do this, please indicate clearly which of the two proposals is relevant to ASENT.

\section{CLOSING DATE: 24 JANUARY 2020.}

It is expected that interviews will be conducted in late January or in February.

www.lse.ac.uk/philosophy/asent-scholarship/ 